\title{
Applied undergraduate Colleges and universities Teaching Several Realizations of probability And statistics Course
}

\author{
jinghua zhang \\ Jingdezhen Ceramic Institute 333000
}

Key words: Applied undergraduate colleges and universities; Probability and statistics course;

\begin{abstract}
Applied undergraduate colleges and universities in recent years, along with the reform of education and talent training mode of big changes have taken place, and probability and statistics course for applied undergraduates is very important, especially for engineering students. This article mainly the probability and statistics course teaching present situation analysis, strategy, to improve the quality of probability and statistics teaching of probability and statistics course teaching reform proposals and reflect three aspects discussed.
\end{abstract}

\section{Teaching experience}

With the reform of college education and the demand of social development, in recent years have taken place for talents training target important change, especially in the education of applied undergraduate colleges. Applied undergraduate colleges and the cultivation of the students in practical application, on the basis of strengthening the student to study application of theoretical knowledge. Now more problems in applied undergraduate colleges and universities teaching, such as teaching evaluation mode single and the traditional teaching mode is difficult to change, etc., the following discusses relevant issues.

\section{Probability and statistics course teaching present situation analysis}

1.1 Give priority to in order to cultivate applied talents. With the development of the society transformation, talented person's demand structure also bigger change happened. Currently applied undergraduate colleges and universities to cultivate the students' comprehensive ability as the main principle, give priority to in order to train applied and technical persons, most colleges and universities began to put forward to develop the teaching aim of technology applied talents. Students in this teaching mode are not only to master the basic theory knowledge, but also have practical application ability. The present education, the teacher gradually realized the important role of practical application, but theoretical knowledge learning or cannot ignore. Many students encountered in practice for data can't use the theoretical knowledge to solve the problem and you don't get information by analyzing the experimental data, therefore the goal of talent training must establish on the basis of the comprehensive training.

1.2 There are many disadvantages of traditional teaching ways. This course involves the knowledge of probability and statistics is various, the traditional way of blackboard writing explanation makes students master the solid theoretical foundation, but the students to learn knowledge not a specific practical application. The student for the course in the right way to learn, many students will be completed the problem solving, a large number of exercises as the main task of learning. Part of the teaching of university teachers is only complete the teaching mission, they lack of interaction with the student in the classroom teaching and lack of the role of guidance and inspiration for student learning.

1.3 Single teaching examination way. Probability and statistics course is a course of practical application, part of the undergraduate course colleges and universities don't attach enough importance to the course of learning and teaching evaluation of a single. Only to the student's final exam scores as the only evaluation standard, although the teacher emphasized the importance of knowledge in the teaching and the school called for attention to the students' creativity, but the present teaching evaluation and personnel training mode there is a deviation. Grasp the situation of 
school evaluation study is subject to a test scores, some students will all energy to cope with the examination by using of study way, then the practical application of probability and statistics course completely ignored.

\section{Improve the quality of probability and statistics teaching strategy}

2.1 Teachers targeted teaching content reform. The current talent training objective of applied undergraduate colleges is given priority to with development of technology applied talents, but the problems existing in the practical teaching is more. Traditional teaching method of teachers entrenched and years of teaching thinking mode in a short period of time is difficult to change. In the undergraduate course colleges and universities teaching material is a complete system, mostly involves the knowledge is more and a lot of pure theoretical knowledge is only to learn knowledge. Most colleges and universities use books belong to the same version, and personnel training direction there is a difference between different colleges, so schools should choose according to their own education pattern to implement versions of college education. Such as some colleges and universities is engineering colleges and universities, some colleges and universities is the normal colleges, both for talents cultivation direction is different, so there should be a focus in the implementation of the teaching content arrangement. So teaching mode should be published in applied undergraduate colleges for applied talents cultivation of excellent teaching material and teaching content reform. Due to the high school has studied classical probability and geometric probability, thus it can be weakened part of the study of probability calculation. For those who applied strong content can be targeted to strengthen learning, teaching content should be consistent with the school personnel training goal.

2.2 Combined with the multimedia teaching. In probability and statistics to study, it is very necessary with the aid of multimedia teaching, such as learning sample variance and the calculation of sample mean, blackboard writing to explain in detail the formula to calculate due to involving in the process of complex and various data, so the teacher can use the modern education technology, such as the related software and so on. Relative density and the calculation process of degrees of freedom is very complex, and the combination of the appendix table query, so student learning is very difficult to calculate. So the teachers can use software and the application of multimedia education technology to assist in teaching mathematics, such as related drawing histogram, bar charts and line charts, students can see clear images through dynamic demonstration. As a center limit theorem for learning, the teacher can use Mathematica software demo, which can reduce the difficulty of calculation and simplify the calculation process, to enhance students' capabilities of application and at the same time to improve the teaching efficiency.

2.3 Seize the key content of teaching and change numerous for brief. Applied undergraduate colleges and universities student's characteristic is the strong ability of practical application and the theory of knowledge learning are relatively weak, so the teacher grasp main contents in the teaching and highlight the difficult point, thus reducing the burden of students' learning, students should know basic calculation method and theory of knowledge. Should be the main focus on cultivating students applying the idea of probability theory and mathematical statistics methods to solve practical problems. On the ability of teacher's teaching principle is grasp the main line, seize the main teaching content, basic concept, basic formula and theorem. On this basis, expand students' thinking, with the introduction of the complex theorems and proofs can be simple, lets the student in line. For students of engineering specialty teachers should be highlighted, the application of knowledge, teachers can make students understand the importance of theoretical knowledge learning in practice and strengthening practice in learning theoretical knowledge of the necessity and significance.

\section{Probability and statistics course teaching reform proposals and reflection}

3.1 Teaching should increase learning interest. Probability and statistics course is the professional learning of important mathematics curriculum in colleges and universities, especially in the 
practical teaching in the classroom, students need to have the rigorous thinking ability. In probability statistics course have a lot of formulas, theorems, math, etc., especially complex probability statistics formulas and calculation process, this is the important reason for the low student interest and learning difficulties. Then in probability and statistics course have a lot of probability reasoning, mathematical symbols and complex formula is various. In this kind of teaching situation teaching teachers should add a lot of fun, rigorous, thoughtful in this kind of logic environment, teachers can more explains the history of mathematics for students or story to increase the humanistic learning, such as teachers in the interpretation of the relevant concept, theorem, can combine the theorem related the story of a mathematician or produce process of this theorem for analysis.For example in the interpretation of the parameter estimation and hypothesis testing, regression analysis and the content such as "variance analysis", teachers can encourage students themselves after class to find related historical materials, let the students to find the relevant mathematical history to understand at that time, mathematicians of the research process and improve students' interest in learning of probability and statistics course.

3.2 In the teaching application cases and combined with the experiment teaching. Strong theoretical probability and statistics courses, teachers can be combined with case teaching method in teaching. The case analysis can guide students to active thinking and the process of problem analysis can provide the students' learning methods, students can according to the case to find their own way to learn. Such as learning "discrete random variable and its distribution law "for Bernoulli experiment and the binomial distribution of learning, teachers can through the relevant case teaching. In the heart of the case teaching process of the experiment is analyzed and strengthen the relevant formulas, students learn knowledge and applied to the case analysis.

Teacher can also through the experimental teaching, such as in learning the binomial distribution, poisson distribution, normal distribution, uniform distribution and exponential distribution model of theoretical knowledge, teachers can apply simulation experiment and through the simulation of process understand the application of the random variables and distribution characteristics, which helps to grasp the nature of the distribution of correlation function. In the teaching of related concepts of sampling distribution, using of excel and SPSS to draw the distribution of related, makes students fully understand the basic methods of simulation.

\section{Conclusion:}

To sum up, in the study of this course of probability and statistics, probability and statistics course teaching of applied undergraduate colleges need theory combined with practice. Especially the teachers' teaching should combine talents training target, applied colleges focusing content and combined with the related teaching software to assist teaching, cultivating students' practical application ability further.

\section{References:}

[1] Liu Li. Applied undergraduate colleges and universities of probability and statistics teaching research [J]. Journal of exam weekly, 2011 (8)

[2] Zhang Kejun. Under the "excellence initiative" probability and statistics curriculum teaching reform exploration applied college $[\mathrm{J}]$. Journal of contemporary education theory and practice, $2015(7)$

[3] Shen Qixia, Zhou Yang. Applied undergraduate probability and statistics teaching research [J]. Journal of comprehensive BBS, 2016 (7) 